\title{
Winter's Al-Ghazali on Disciplining the Soul
}

\section{Yasien Mohamed}

Al-Ghazālī on Disciplining the Soul (Kitāb Riyadāt al-Nafs) and On Breaking the Two Desires (Kitäb Kasr al-Shahwatayn)_Books XXII and XXIII of the Revival of the Religious Sciences (Ihyä' 'Ulüm al-Dīn). Islamic Texts Society, Cambridge, 1995, translation with notes and Introduction by T.J. Winter.

Winter's translation is the first accurate translation of Books XXII and XXIII of the Ihyä' (Revival) into English. Although Fazlul Karim's Imam Gazzāti's Ihya $\vec{a}$ ' Ulum al-Din was an attempt at translating the Ihy $\vec{a}^{\prime}$ (Revival) in four volumes, it is in fact an abridged and mutilated translation. ${ }^{1}$ Winter's translation is also supported by a scholarly introduction and notes; therefore, my review will focus on two aspects: the scholarly approach of the author and the quality of his translation.

We shall present a critical evaluation of Winter's text as a whole. When comparing the English text with the original Arabic, it is to assess whether the translator managed to capture the content, message, and style of the Ihya $\vec{a}^{\prime}$. We also pay attention to the choice of words, particularly the English equivalents of key Arabic terms. As a kind of practical criticism we look at the scholarly and literary style of the introduction in the form of book reviewing and subject the text to "literary appreciation" as an academic exercise in critical reading.

Winter's study of Al-Ghazāli's ethics in English is just one of the contributions that have emerged in recent years. Among those worthy of mentioning is Sherif's Ghazāti's Theory of Virtue, which deals mainly with philosophic, religious, and mystical virtues. Unlike Winter, he regards the Mizān al-Amal as an authentic work by Al-Ghazălı and makes frequent reference to it. Sherif divides his book into thirty sections, of which the fourth discourse- "The Refinement of the Soul"overlaps with Book XX and XXIII of Winter's translation of the Ihya '.

Yasien Mohamed is the chairperson of the Department of Arabic Studies at the University of the Western Cape, South Africa. 
Also worthy of mentioning is Umaruuddin's The Ethical Philosophy of $A l-G h a z \bar{a} l \hat{l},{ }^{2}$ which is based on the Ihyä' and the Mizän al-'Amal, and is supplemented by classical and modern scholars' writings on Al-Ghazālit. His book is divided into four parts: Parts 2 and 3 deal specifically with Al-Ghazāli's theory of ethics (the principles), and part 4 deals with the practical aspects of vices and virtues. Unlike Sherif, Umaru-ud-din covers the historical background to Al-Ghazâlı and the psychological nature of man. Both studies are scholarly as well as very readable and illuminating. Winter's Al-Ghazâti on Disciplining the Soul has the advantage of being both a study of Al-Ghazāli's ethics and a translation in one volume. Another unique feature of Winter's study is that, historically, he situates Al-Ghazāli’s ethics within the framework of Sufism; moreover, it is presented in a manner that makes it fully intelligible to the modern Western reader. We also show that Winter's attempt to capture the persuasive style of Al-Ghazālı makes it a book that is appealing to the Muslim reader as well.

\section{Introduction}

Winter's work is a scholarly contribution. He presents a critical introduction to the translated text, placing it, historically, in the context of Islamic ethics. In addition, he provides explanatory notes and cross-references to Al-Ghazäti's works, as well as other primary and secondary sources on classical Islamic ethics.

His introduction has seven sections which contain the following: (1) an introduction to Al-Ghazātì with specific reference to Sufism and the Ihy $\bar{a}$; (2) the scriptural basis for Sufi teaching, particularly pertaining to the vision of God, intuitive cognition, the soul (nafs), and character ( $k h u$ luq); (3) the early Sufic teaching on eating, drinking, sleeping, praying, fasting, talking, doing without (zuhd), fear, and hope; (4) the question of ethics, especially in view of early Sufi asceticism and the later Sufi transcendence of the self; (5) the method of refining character; (6) Sufism and classical Islam's moderate approach to sexuality, which is characteristic of Al-Ghazāli's teachings; (7) the influence of philosophical ethics and the historical context for Al-Ghazali's ethics.

The style of Winter's introduction is both scholarly and literary. One of the academic approaches that he uses to study religion is the historical. For example, on the subject of Sufism, Winter provides numerous historical explanations of the Sufi phenomenon in early Islamic history:

Many forms of early Islamic piety were inspired by rejection of Umayyad rule, either in the form of armed dissent, as in the case of the Shi'ite and the Khärijı sects, or in the guise of a severe, worlddenying asceticism. This latter tendency, which looked for inspiration to the example of certain companions of the Prophet, and of the 
subsequent generation (the so-called followers), verged at times on a penitential self-contempt which seems closer to primitive Christianity than to the austere but essentially moderate example of the Prophet. (XXXIII)

Winter elaborates on this point in response to Massignon's verdict that the "Islamic credentials of Sufism" should not obscure the fact that there has been substantial Christian influence on certain forms of Muslim piety, particularly Christian attitudes to the world and the flesh (XXXIII). The author substantiates his arguments with concrete examples from classical Arabic and Western scholarly works. For instance Winter notes the following:

In contrast to the Prophetic practice of fasting regularly but who forbade his companions to fast every day, Ibrahim ibn Adham (d. $161 \mathrm{AH} / 777 \mathrm{AD}$ ), who lived in seclusion in a Basrah mosque, would eat only once every three days. Regarding sexuality, al-Darani remarked: "whoever marries has inclined towards the world" is more reminiscent of Christian sexuality than of the Arabian Prophet. The impact of Christian influence on Muslim ideals is inevitable as Muslim attitudes to Christians during the Umayyads were often "respectful."

Winter is clearly addressing himself to a Western readership familiar with the Christian tradition. This is also evident from his endnote reference to English academic sources by Andrae, Fuchs, Massignon, Mole, and Arbesmann, all of whom refer to the early Christian attitudes to hunger, fasting, and sexuality (Winter, 1995: XVII). The book would therefore be of interest not only to the Western historian but also the theologian and the Sufi-minded person.

Having identified the extra-Islamic influences on Sufism, Winter traces some landmark efforts to moderate the excesses that have crept into Sufi attitudes to the flesh and the world. Again, he treats the subject comparatively to make it more interesting to the secular and Christian reader:

Unlike the Desert Fathers of the church, however, the Sufis normally professed a spirituality which confronted the trials of everyday life, and where possible, sought to ameliorate the lot of others.

According to Winter, the science of the soul relates more to practical ethics than to philosophical ethics. It is the main concern of the Ihya ${ }^{\prime}$, making it more appealing to the Muslim readers than the more philosophical approach of Miskawayh and Isfahani. Al-Ghazāli seems to have left the "higher metaphysical realities" to the Mishkat al-Anwär and the 
Mizān al-Amal; however, to guide the initiate as well as to arouse the uninitiated, he discusses the rüh and the mystical stages in the Ihy $\bar{a}^{y}$.

Winter clarifies his point about the "soul" linguistically; he makes a distinction between the imperishable rüh (spirit) and the mortal soul (nafs) that develops to higher levels of psychospirituality. Again, thinking of the Western reader familiar with Greek and Latin, he introduces the corresponding terms for the soul (anima; psyche) and the spirit (pneuma; spiritus). And again, comparing with Christianity, he alludes to the Christian influence, where the lower soul is likened to an animal to be killed rather than to be trained, like a dog or a horse. But later teaching, more in line with a moderate Sufism, stressed that the animal should be disciplined rather than killed, for even the "stubbornest horse can become a well-trained steed, a necessary aid on the spiritual path" (XXIX). In the endnote Winter explains his preference for "soul" instead of the psychological terms of "self" or "ego." Being fully conscious of the ambiguity of the translated terms, Winter says:

The translation is of course unsatisfactory, and leads to many ambiguities (which are, however, not always infertile). But "soul" seems preferable to "ego" or "self" in a text such as the present one, which includes ideas of a philosophical character. (LXXVI)

Winter prepares the contemporary reader for the Sufi themes of "The Discipline of the Soul" and "The Breaking of the Two Desires," which are presented by Al-Ghazālı within a Sufi framework of ethics. After discussing the four Sufi ascetic practices-solitude, silence, hunger, and sleeplessness-Winter moves to "ethics and self-transcendence," stressing the virtues that transcend the selfish self and that are not only preoccupied with the reform of the soul but also with the moral and social virtues of Islam. Stress is on goodness of character (husn al-khuluq), a condition and product of religious life, expressed mainly through the virtues of humility (tawädu $\left.u^{i}\right)$ and selflessness (ithär).

These four principles of the spiritual path were, in a sense, selfish, being directed only to the reform of the individual soul. They were complemented, however, by an attention to the moral and social virtues of Islam, which they were believed to improve. Great stress was laid on goodness of character (husn al-khuluq), as being both a condition and a product of the religious life. "Refining (tahdhib) the character is one of the methods of self-discipline." (XXXII)

Winter lucidly explains the historical context and philosophical influences of Al-Ghazāli's notion of acquiring noble character traits. He states that in Al-Ghazāli's time it was treated more systematically. "The Platonic notion of the philosophical life as an attempt to become similar to God was increasingly in the air" (Winter, 1995:XXXIV). It was sup- 
ported by the hadith, takhallaqū bi akhlāqi llâh (acquire the character traits of God), hinting that through ethics man could reclaim his theomorphic nature. Meditating upon the moral implication of the names is a method of discarding the ugly and nurturing the beautiful traits of the soul, thereby enabling one to receive divine light (XXXIV). Divine character traits, which are innate in man's primordial disposition (fitrah), are even a key principle of the spiritual path for Ibn 'Arabi.

Speaking of the acquisition of the character traits of God infers that ethics could be the path to reclaiming "man's theomorphic nature." This idea inspired Al-Ghazālı to write Maqsad al-Asnā (The Highest Aim) in which he lists the ninety-nine names of God and explains how man can assume the nature associated with it. In this work Al-Ghazālı states that man must

strive to adopt and acquire what is possible [for him] of these attributes, and adom himself with their beauties, for thus does man become Lordly (rabbani), that is, close to the Exalted Lord, and become a companion to the Highest Host of angels. (Winter, 1995: XXXIV)

The Sufi method of arriving at the Names is through dhikr-a contemplation of the divine names to acquire proximity to God and the makärim (noble traits) - made possible by the innate nature of man, his fitrah. Khalq (human creation) thus becomes the potential for khuluq (the actual moral character). The notion of the imitation of God runs through philosophical Islamic ethics.

By meditating upon the moral implications of these names, one is able to discard the ugly and nurture the beautiful:

Khuluq (character trait) is therefore inseparable from khalq (creation, created nature); and it is thus that man must make use of the "hidden correspondence" which exists between him and his Maker in order to return to Him by His attributes. (Winter, 1995:XXXV)

In his notes, Winter makes no mention of al-Rāghib al-Ișfahānī, who also expounds the notion of the imitation of $\mathrm{God},{ }^{3}$ and who had a profound influence on the ethical thought of Al-Ghazālit.

Winter presents an accurate and well-balanced account of Sufism and sexuality. His style suggests a writer with controlled convictions, which are clearly reflected in his comparison of the Islamic and the Christian view of sexuality and womanhood. His comparison addresses the average Westerner's misconception of a sex-ridden Islam with a licentious Prophet. Based on classical and modern works, Winter compares Islam's positive approach to sexuality with the negative approach of ascetic Christianity. 
Christian and Muslim ascetics may have agreed on the value of hunger as a means of self-discipline, but on a rather more intractable matter of sex, they trod very different paths. Inspired by the vision of a celibate Christ, preoccupied with the notion of original sin and the subsequent curse of concupiscence transmitted to Adam's progeny ... Christianity produced a remarkable catalogue of exploits against the demon of lust. (Winter, 1995:XXIV)

The tone of the foregoing passage might suggest that the author is biased toward Islam, but in fact he is making a scholarly factual comparison to dispel the misconceptions Westerners have of Islam. Islam, by contrast, is preoccupied with the notion of original goodness (fitrah), where the world is not to be renounced but to be enjoyed. Its positive attitude toward marriage and sexual expression in private (but not in public) has earned the contempt of many Christian scholars:

Miguel Asin Palacious (d. 1944), the Spanish priest who gave us the finest account of Islamic eschatological belief, does not trouble to hide his distaste. Confronted with the information that in heaven men will consort with their wives, he betrays a contempt which stands entirely in the tradition of medieval polemicists of the type of Ramon Lull. ... Hans Kung, too, adduces the Prophet's "sensual lifestyle" as evidence against the authenticity of his mission. (Winter, 1995:LXXXIX)

Winter uses "contempt" 4 to describe the Christian negativity to the positive Islamic view of sexuality as if he is expressing his contempt for their unjustified though rationally explicable prejudice toward Islam. I doubt whether one can accuse Winter of being apologetic about Islam. $\mathrm{He}$ is merely contrasting, in a scholarly manner, the different approaches to sexuality that can be understood by both Christian and Muslim readers. Although Al-Ghazāli does not make any reference to Christianity in Books XXII and XXIII, it becomes obvious that Winter is responding to the Western challenges prevalent today in modern society. The only link this discussion has with the translation is "The Discourse on Sexual Desire" in Book XXIII of the Ihya '.

Again, in defense of Muslim women in Islam, Winter turns to the Islamic notion of sexual expression "as a clue to the highly-charged debate about the status of Muslim women." He makes a special effort to clarify the debate and to provide the "essential background" to the general readers who are accustomed to negative images of Islamic women.

But an understanding of Ghazali's text will be substantially enhanced if we bear in mind some essential background, which may, perhaps, be startling to non-specialist readers accustomed to resolutely anti-female images of Islam. (Winter, 1995:XXXVII) 
In the notes to the introduction, Winter identifies some recent scholarly attempts to "challenge Western stereotypes of Muslim women." Presumably, feminist trends have also played a role in gender consciousness of modern liberal society. Partly in response to these trends, Winter tries to show, by comparing the Christian and Islamic concept of God, that Islam offers more scope to female spirituality than Christianity. His argument runs as follows:

Gender differentiation can be perceived within the Christian concept of God as "Father." The honour accorded to the male principle was further reinforced by the "incarnation," from which a male vessel in the form of Jesus was chosen. Islam, by contrast, did not call God, "Father," nor did it recognise the incarnation. The metaphysical assumption, therefore, is that in principle Islam did not "exclude the possibility that a high status might be accorded to women and to female spirituality." (Winter, 1995:XXXVII)

Clearly, Winter is not only making Al-Ghazālı comprehensible to the modern readers, he is also pointing out their negative stereotypes regarding Muslim women. ${ }^{5}$ As regards the ideals of female sanctity, Winter again compares the Islamic and Christian views of womanhood. Christian female saints were mostly celibate, drawing inspiration from Mary, the mother of Christ. Muslim women also have reverence for Mary; but in practice, they choose Fatima, the Prophet's daughter, as their feminine ideal.

Fatima was at once saint, wife, and mother, whose nearness to God seemed to have been confirmed rather than compromised by her biological fulfilment. As the fertile soil of the ahlil bayt, the privileged and saintly descendants of the Prophet, she gave to Muslim women a paradigm of fulfilment, and to men a sign that sanctity was not excluded by the normal functions of womanhood. (Winter, 1995: XXXIX)

This section concludes with Winter's point that celibacy among Muslim ascetics was not the norm; these people were often frowned upon as pious eccentrics who have not followed the practices of the Sunnah. Strict sexual abstinence was the rule of Christian monastic piety and this seemed to have had a powerful influence on the practice of Muslim ascetics. This is the exception to the rule in Islam which encourages a positive sexuality within the framework of marriage.

Al-Ghazāli is a convincing theorist of moderation in classical Islam. From his treatment we can see that although extravagances abound in the hagiographies, these finally serve to show the reader the benefit of the golden mean, which was identified with the way of the Prophet. 
More significant than the impact of Christianity was the impact of the Greek philosophical legacy. Muslims attempted to reconcile it with Islam; but this enterprise led to many controversies within Muslim history. There was no shortage of religious scholars schooled in the traditional disciplines to pronounce "anathemas against those who drank from such polluted springs." (Winter, 1995:XLVI)

After providing the historical context, with reference to Arabic and English sources, Winter focuses, on the field of ethics. Al-Ghazāli condemned the Muslim philosophers for their heresy, but as Winter remarks, he was not a crude "fundamentalist," opposed to learning from a foreign source. He was opposed to their conclusions but was open to the truth from wherever it came ${ }^{7}$ (Winter, 1995:XLVII).

Al-Ghazālı was aware of the debt of Ash'arite theology to Greek ideas; this is evident in the works of his teacher, Al-Juwayni (d. 478/1085), who introduced a philosophical approach to epistemology. Winter makes an important point about the influence of Greek thought on Al-Ghazātı via Muslim philosophers:

The channels were usually indirect, and there is little evidence to suggest that Ghazali ever studied Aristotle directly, as he preferred to read the Arab philosopher, whose ideas presented the more immediate challenge to the Ash'arite position; but their very indirectness made them the more efficient in infiltrating the thought of his school; for it was emotionally easier for a devout Muslim to borrow ideas from a Muslim philosopher, even with heretical notions about the afterlife, than it was to borrow directly from ancient sources which did not even nod in the direction of Islam. (Winter, 1995:XLIX)

Al-Ghazāli identifies six disciplines: mathematics, logic, the natural sciences, theology, politics and ethics. The first three are morally neutral; but theology contains the "bulk of their errors" since the philosopher has denied bodily resurrection, God's knowledge of particulars, and the createdness of the world. As for ethics, AlGhazâli states: "the nature of the soul and its discipline came from the writings of the Sufis who remember God and fight passion. The philosophers adomed their words with their own, hoping that they might spread their falsehood abroad" (al-Munqidh, 24). Philosophical ethics, then, need not be rejected by the Muslim intellectual; but one must guard against two things: Great thought tainted with infidelity; and, the delusion of philosophical work diluted with Prophetic material. (Winter, 1995:L-LI)

Winter gives a concise account of moral philosophy: Plotinus' concept of the Higher Soul (the One), Galen's Platonic psychology, Ikhwān's 
Neoplatonic concept of fitrah (man's innate receptivity to goodness), Yahya ibn 'Adi's innate traits of vice and virtue, and Ibn Sina's philosophic psychology which forms the basis for the moral philosophy of Miskawayh. Surprisingly, for a scholarly review of the classical moral philosophers, no mention is made of Al-Rāghib al-Ișfahānı̄'s ethics, or his impact on Al-Ghazāli.

Thus, like the wise snake handler who will not perform his craft in front of his son lest he emulate him and be bitten, according to AlGhazālit, people without sufficient intellectual training should not read such philosophical works.

In accordance with his last principle, Ghazali has evidently striven to exclude direct references to the philosophers from his more popular works, including the Ihyä'. This confronts the modern student with serious difficulties when attempting to trace the pedigree of his ideas, particularly those of a metaphysical nature. With ethics, however, the task is a little easier, partly because the large-scale introduction of Greek ethics into Muslim thought had begun rather later than was the case with metaphysics. The text here translated, together with one or two of Ghazali's other works, contains long passages whose lineage stretches unmistakeably back to Plato, Aristotle, and, in a lesser degree, to the Stoics and to Galen. (Winter, 1995:LI)

Al-Ghazāli does not acknowledge the Greek philosophers, but to what extent does he acknowledge the Muslim moral philosophers? Winter places Al-Ghazāli's ethics in the historical context of moral philosophers who have influenced him. He touches on Aristotle's doctrine of the mean between the two extremes. For example, anger is a morally neutral quality; but through training it can either turn to "righteous indignation" or defiance of what is just (Winter, 1995:LII). ${ }^{8}$ Unfortunately, no mention is made of Al-Ișfahānī whose positive sense of anger could have influenced Al-Ghazäli.

Winter traces the important Muslim philosophers who dealt with ethics in varying degrees, including Al-Kindi (d. 256/870), Al-Razi (d. 313/925), the Bretheren of Purity, the Christian Yahya ibn 'Adi (d. 364/974), Abu 'Ali ibn Sina (d. 428/1037), Abu 'Ali Ahmad ibn Miskawayh (d. 421/1030), and Al-Mawardi (d. 450/1058). Miskawayh was the most successful in providing the "fullest Muslim synthesis" of the Platonic and Aristotelian systems. Winter states: "[The Refinement of Character] was popular not so much for its originality as for its author's talent for synthesising Platonic, Aristotelian, and Islamic ideas on the moral life, cast in a pleasing Arabic style and adorned with quotations from sources as varied as Homer, Aristotle, Galen, Pythagoras, Al-Kindi, Al-Hasan al-Basri, and the Qur'an" (Winter, 1995:LIV). This work 
served as a model for Al-Ghazālı and other Muslim moral philosophers of his time.

Winter has given a beautiful outline of moral philosophers and mentions specifically Miskawayh's impact on Al-Ghazāli; but makes no mention of Al-Rāghib al-Ișfahānī (d. 502/1108), who wrote an important ethical treatise al-Dhari'ah ila Makārim al-Sharīah and which had a major impact on the ethical thought of al- Ghazali, evident from the close resemblance between Mizān al-'Amal ${ }^{9}$ and al-Dhari' ${ }^{\circ} a h .^{10}$

Winter is correct in stating that Al-Ghazāli was more inclined to make use of Muslim philosophical sources, than to go directly to the Greek originals. This is proven with Miskawayh and Isfahani's ethics; but unfortunately, Winter does not seem to be aware of the ethical contribution of Isfahani's ethics even though an edited version of the Arabic text by 'Ajami appeared in 1987, and Fakhry wrote a brief synopsis of Isfahani's main ethical ideas in 1991. Before this, Sherif alluded to the parallels between al-Dharī'ah and Mizän al-'Amal as early as $1975 .{ }^{11}$ The most recent study by Mohamed placed Ișfahānin in the context of the legacy of Islamic ethics, and showed, after close textual comparison, Ișfahânì's impact on Al-Ghazālı.

After a summary of the 10 sections of Book 22, and each of the 8 sections of Book 23 of the Ihy $\vec{a}^{\prime}$, Winter proceeds with his notes for which we have a word to say: There is no reference (or citation) to Isfahani or his major ethical treatise al-Dharīah ila Makärim al-Sharī'ah. Nor is there any reference to Al-Ghazāli's major ethical treatise, Mizān al'Amal. These omissions reflect a serious shortcoming to Winter's introduction and notes. About the rest of his notes, relating to the technical aspects of scholarly style, we have only positive comments to make. ${ }^{12}$

\section{The Translation}

The purpose of the Ihy $\bar{a}^{\prime}$ is to persuade the listener or reader to refine his or her character. Winter succeeds in capturing this purpose in his translation. His translation is also intended for a scholarly readership. It is an academic translation which has useful explanatory notes and references to parallel sources.

His translation is not so much a literal translation (where grammatical structures are transferred) but a faithful and academic translation which is close to the Arabic text, and yet still in idiomatic English. ${ }^{13}$ One may also refer to Winter's translation as an orientalist translation, in that he is scientifically accurate (with notes and a critical introduction); but unlike the coldness of many orientalist translations, Winter's is warm with feeling (without being sentimental); in addition, it is readable, with an elegant style that makes it appealing to the nonprofessional reader. ${ }^{14}$ 
Although the richness and poetic beauty of Al-Ghazāli's Arabic is not captured by the translation, Winter succeeds in capturing its maturity of feeling and conviction. There is a sense of control over his language; he does not make Al-Ghazāli sound too emotional or too sentimental. Clearly, the purpose of Al-Ghazâli's writing is to change the heart of the believer through citing religious authority; to provide moral lessons through his anecdotes from religious and Sufi personalities; and to present logical arguments through contrasts and similes that appeal to the rationally minded. The appeal to reason and the use of revelation are combined mainly in Book 21 of the Ihya ', having different readers or listeners in mind. The literary style, particularly the poetry, is difficult to capture in the English, and poetic prose would seem unnnatural today, but for 11th century Baghdad, it was normal. Muslim religious philosophers such as Mawardi and Isfahani not only included poems in their ethical works, but their very style was characterized by rich poetic prose. ${ }^{15}$ Nevertheless, in spite of the inevitable loss of meaning due to translation and style, Winter manages to present a controlled, concise, and elegant style that captures something of the seriousness of purpose and majesty of style of the original.

A faithful translation attempts to produce the precise contextual meaning of the original within the constraints of the target language's grammatical structures. It "transfers" cultural words and preserves the degree of grammatical and lexical "abnormality" (deviations from source language norms) in the translation. It attempts (like Winter's translation) to be completely faithful to the intentions and the text realizations of the source language writer (Winter, 1995:XLVII).

Al-Ghazāli is conscious of the fact that he is addressing himself to different segments of the Muslim community - the layman and the intellectual; thus, in justifying the variation in his literary style, he says:

There are many statements of this nature, but they all treat of the fruit of good character, not its essence; neither do they succeed even in encompassing all of these fruits. Since to unveil its true nature is more important than to cite various sayings, we shall proceed with our discourse as follows.

The discourse which follows is of a philosophical nature, written in a philosophical style to bring out the "essence" of good nature. In the preceding paragraphs, the author cites a few sayings pertaining to the definitions of good character by Sufi scholars such as Hasan al-Bașrī (d. 110/728), Shah al-Kirmani (d. 300/913), Sahl Ibn 'Abd Allah al-Tuștari (d. 283/896), the companion 'Alı ibn 'Abi Țālib (d. 40/661), Abu Sa'id al-Kharraz (d. 279/892), and Al-Husayn ibn Mansur al-Hallaj (d. 309/922). In Appendix 1, Winter provides brief biographical detail of all persons cited in the text. Most of the persons cited in this passage are of 
Sufi persuasion. Winter also cites page references to works for more biographical information.

The philosophical style is intended to "unveil the true nature of things" and not merely their "fruits"; it is to penetrate the heart of the matter. In the philosophical passage, the author suggests that creation ( khalq) and character (khuluq) can be used interchangeably, as "So and so is good in his creation and in his character"; that is, both his outward and inward aspects are good. The body perceives with "ocular vision," but the soul is of greater worth: it perceives with "inner insight" (bașirah). AlGhazālı cites a Qur'anic verse to suggest that the body is ascribed to clay and the soul (rüh) to God. A trait of character, then, is a firmly established condition (haya) of the soul, from which actions proceed easily without any thinking or forethought (Winter, 1995:XVII).

A detailed footnote which reflects Winter's scholarly approach follows this quotation. He traces the influences of the definition of character from primary and secondary sources, but no mention is made of Isfahani. The source of this definition in an ethical treatise by Galen. Winter is certain, upon examining the wording, that Al-Ghazâlı took this definition from Galen. However, he has not even considered whether it might have come directly from Isfahani. Galen might have been the original source, but where did Al-Ghazâlı take it from? Al-Ghazālı elaborates upon this condition:

If this condition is disposed towards good deeds, it is called "good character trait"; but if towards bad deeds, it is called "bad character traits." It is a firmly established condition (rasikha) whereby a person is regarded as generous if he is consistently generous; and acts generously easily and without thinking. But one who is generous sometimes, or makes a show of generosity, has not this quality fixed in his soul. (Winter, 1995:XVII-XVIII)

A successful metaphor is used to "to clarify and enrich" something with "precision and vividness," using content that is not remote from our experience. ${ }^{16}$ In this section of Refining Character, Al-Ghazāli uses a medical metaphor current at his time. Just as the body falls sick when the four humors (akhlät) are out of equilibrium, so too does the soul become sick when the four cardinal virtues are imbalanced. (The main source is Miskawayh who used Galen's medico-philosophical synthesis, a combination of the psychology of Plato and the medicine of Hippocrates, together with the physics of Aristotle. ${ }^{17}$ ) Al-Ghazâli urges the struggle against desire to achieve equilibrium and liberation of the soul. He uses the image of the student calligrapher who is forced initially to struggle and to imitate a good hand. In the same manner, the Sufi novice should undergo hardship in imitating his spiritual teacher. 
$\mathrm{Al}$-Ghazālì tries to convince and persuade the reader to realize the evil, disastrous consequences of "foul characteristics" while comparing them with the value of "fair characteristics."

Foul characteristics are sickness of the heart which deprives man of "everlasting life." This cannot be compared with the sickness of which cause the loss of "corporeal life." Doctors treat the illness of the body, which had only the "transient life"; but not of the sound "heart" which lead the "eternal life."

To illustrate the value of treating the heart, he juxtaposes transient life with the external life-medical disease with spiritual disease. The analogy of the physician is popular in Sufi classical literature. He provides a tangible, concrete example from daily experience to draw home the need to be even more concemed and anxious about spiritual disease; for example, neglecting a disease of the heart will lead to more frequent and powerful disorders. Now that the reader is persuaded, he says:

A bondsman thus needs to meditate in such a way as to learn the origins and causes of the sicknesses, and then to roll up his sleeves, to treat them and set them aright.

Having diagnosed the root cause of his spiritual disease, the reader must now act to remedy the situation. He must go for the treatment to provide him with spiritual success.

The author uses the analogy of the body and the soul to also explain Islamic epistemology in section 22.2, albeit briefly; that is, the difference between physical sight (basar) and spiritual sight (bașirah). This is characterized elsewhere in the Ihy $\vec{a}$ ' with more detail. The point is that the body and soul analogy features throughout the writings of Al-Ghazāli and the classical moral philosophers.

After convincing the reader to look at the cause of the disease of the heart, the author convinces him further by the use of authoritative religious citations on the merits of good character, followed by the indications of the diseases of the heart and the general approach toward the remedy. The specific treatment for specific ailments follow much later in the Ihya $\bar{a}$; but first the author wants to prepare the religious and philosophical grounds for convincing the audience, both the general public and the intellectual elite.

Having in mind the different types of readers, the author varies his style according to the level of the discourse. Winter manages to capture the difference in the author's approach to the subject. Al-Ghazāli himself makes plain that he uses the metaphor for the "body" to make more intelligible the discussion of the refinement of character: 
In the course of this discussion, we shall make use of the symbol of the treatment of the body, in order to render the matter more easily understood.

Where Al-Ghazālı emphatically calls for action, it is presented with this in mind by the translator as if to say the translator himself is calling for action, having in mind the modern reader who is receptive to such persuasion. He could have translated this extraction literally, and yet without effect on the reader.

Winter's translation is easier and more effective: "And then to role up the sleeves." The translator's use of the English idiom is not found in the original, but it urges the reader to action.

Al-Ghazāli concludes this section with the subsidiary virtues that emerge from the four cardinal virtues of wisdom, courage, temperance, and justice. For example, concerning courage, "this gives rise to nobility (karam), intrepidity (najda), manliness (shahäma), greatness of soul, endurance (ihtimāl) . . ." etc. Winter provides the Arabic in square brackets for each of these English terms but not for those terms which have more than one Arabic term, as reflected in variant readings of other Arabic editions. "Greatness of soul," for example, reads as kibr al-nafs or kasr al-nafs in the end notes to the translation.

Of the subsidiary virtues arising from temperance are modesty (hay $\bar{a}$ ) and scrupulousness (wara). Winter explains the Greek origin of these ethical terms and sometimes indicates the point of conflict with Islamic ideals. For example, in a footnote on modesty he states: "Here we have an example of conflict between Greek and Islamic Ideals; Modesty was not recognized as a virtue by Aristotle, ${ }^{18}$ but had been stressed by the Prophet: 'Modesty comes from faith' (Bukhari and Muslim), and included by Miskawayh."19

We have a problem with the English word "modesty" because it does not convey the precise meaning of hayā. Haya in the Aristotelian sense is more appropriately translated as "shame," as it signifies humiliating disgrace such as is caused by an illicit union, etc. Since Winter does not explain what Aristotle means by it, the reader could interpret it as being "chaste," and the impression given is that Aristotle does not approve of chastity. Lane translates hayā (and its synonym hishma) as "shame: the shrinking of the soul from foul conduct through fear of blame." The Lisān al-Arab also views hishmã as synonymous to hayā. The word "modesty" has many English associations that do not convey the meaning of hayā. The translation "shame" more accurately conveys the meaning in the Ghazalian, Aristotelian, and Miskawayhian sense. ${ }^{20}$

In section 22.1, in an exposition of the merits of good character and condemnation of bad character, Al-Ghazālı uses Qur'anic citations, hadiths, and exhortations to convince the reader. The use of religious 
authority through textual evidence in this and most other sections of the Ihy $\bar{a}^{\prime}$ is aimed at being convincing and persuasive. Religious textual citations are also used to expound on Islamic doctrines. In an opening paragraph he quotes the Prophet's wife:

And 'A'isha (may God be pleased with her) said, "The character of the Emissary of God (may God bless him and grant him peace) was the Qur'an."

Winter has attempted a literal translation of the hadith. He translates the expressions of respect and reverence for the Prophet and his companions. He could have used abbreviations such as "RAA" and "SAAW" to be more concise but he preferred to translate them completely. In an explanatory note to the above hadith for the benefit of the contemporary reader, he states: "This simply means that the 'medium was the message,' to borrow a modern proverb." By this expression Winter wants to emphasize the point of the hadith, which is that the Prophet was the ideal standard of the virtues expounded in the Book. In the paragraph before this, Al-Ghazāli quotes a verse from the Qur'an, and Winter provides its historical context and cross-references to Sufi interpretations of it.

The technical aspects of the notes make Winter's work a scholarly, precise piece of literature. The meanings of Arabic terms are given in brackets within the text. The Arabic equivalent of English terms used in the text are also provided in the footnote. For example, on the same page (7), he cites a hadith: "The heaviest things to be placed in the Scales shall be the fear of God and good character." The footnote reads: "al-Mizän, the scales in which good and evil deeds will be weighed against each other on the day of judgement."

To compensate for the obscurity or loss of meaning in a piece of translation on page 8, Winter states in a footnote: "The point of the anecdote, somewhat obscured in translation, is to demonstrate the importance of good character, and its complete exemplification by the Prophet."

The elaboration of a point or concept appears at times in another place in the text. For example, the juxtaposition of khalq and khuluq cited in a hadith (Winter, 1995:VIII) is explained in another passage in the text. Winter, in the footnote refers the reader to page 6 for Al-Ghazâli's elaboration of the concept.

Note the meaning of virtue in the following hadith: "The honour of a Muslim is his religion, his lineage is good character, and his virtue is his intellect ('aql)."

The Arabic equivalent for virtue, muruwwa, is given in a footnote. Winter then explains that this trait was extolled in pre-Islamic Arabia and the hadith is typical of the Prophet's challenge to the "egotistical and tribal values" of the pre-Islamic period. Winter also provides useful crossreferences by Bravmann, Golxiher, and Isutzu. However, I think the 
reader is still left wondering: What is meant by "virtue"? Winter explains the concept as follows: "Murruwa is derived from 'mar', 'man', and hence, has the connotation akin to the Latin 'virtus'." While this explanation is useful to those who know Latin and Arabic, it does not help the English reader. In the absence of a suitable English equavalent, Winter could have inserted a footnote to explain the meaning of "virtue."

\section{Conclusion}

We now come to definite conclusions about Winter's translation and scholarly study of Al-Ghazăli's ethics. A major shortcoming is that he did not acknowledge the impact Isfahani had on Al-Ghazâtı's ethics; nor did he acknowledge or make reference to al-Mizān as Al-Ghazāli's major ethical treatise. Despite these limitations, Winter's work is marked by scientific accuracy and an elegant style; it is a significant contribution to English literature on Al-Ghazāli's ethics, both as a translation and as a scholarly study. It is a book that should benefit the seeker of spiritual and moral refinement, as well as the scholar of mystical and ethical thought.

\section{Notes}

1. Fazlul-Karim, Imam Gazzali's Ihyầ' 'Ulum-al-Din. Book III. (Lahore, n.d.).

2. Muhammad Umaruddin, The Ethical Philosophy of Al-Ghazäli (Aligarh, 1962).

3. Rāghib starts off his ethical treatise with "absolute noble equalities such as wisdom, generosity, knowledge forbearance, and pardon" which can be used to describe God. Yasien Mohamed, "The Ethical Philosophy of al-Rāghib al-Ișfahānī," in Journal of Islamic Studies 6, 1 (Oxford, 1995), p. 58; see also p. 42 (note 10). Elsewhere, Ranghib describes them as leading to the imitation of God according to human ability. The acquisition of the noble qualities (makärim) qualifies one for khalifah. This Neoplatonic notion of imitating God became the foundation of Islamic political philosophy. See Hans Daiber, "Political Philosophy," in History of Islamic Philosophy, Vol 1, Sayyed Hossein Nasr and Oliver Leaman (eds.) (London and New York, 1996), p. 852; and Mohamed, "The Ethical Philosophy," p. 58.

4. "Contempt" means an attitude to something which one despises as worthless, insignificant, or vile.

5. Feminist trends in the English liberal society have also been critical of the position of women in Islamic society.

6. The rich imagery "polluted springs" refers to the Greek philosophical legacy.

7. Interestingly, Winter defends Al-Ghazălı by stating that he is not a fundamentalist (note the modern usage of the term), and he cites a hadith to prove that a Muslim will even learn wisdom from the Greeks. Why should Winter cite the authority of the hadith to defend Al-Ghazāli's open mindedness, when we know that Al-Ghazāli has been receptive to Greek thought without him (Winter) having to prove it by a hadith?

8. Winter appropriately uses "righteous indignation" to express moderate anger aroused by something one considers mean. The irascible faculty, when disciplined, expresses this positive anger. Al-Ghazäli's ghadab (anger), linguistically, does not connote this meaning precisely when compared to Ișfahānī's hamiyyah. For a positive use of anger, Al-Ghazãti uses ghadabiyyah along with hamiyyah. See Mohamed, "Ethical Philosophy," pp. 56-57.

9. According to M.A. Sherif, The Criterion (Mizān) is an authentic ethical work of Al-Ghazăhı, confirmed by L. Massignon, M. Bouyges, G.F. Hourani, and Abdurahman Badawi. Thus, it is a major shortcoming in Winter's commentary to leave out the Mizān as the main source for Al-Ghazâli's ethics. The doubt in the authenticity of the Mizān might have to do with the fact that many of its passages were taken from Isfahani's ethical treatise, al-Dharī'ah ila Makärim al-Sharīah. It is possible that when Al-Ghazäli 
quoted from the al-Dharitah, his students might have thought the dictation was entirely the words of Al-Ghazāli. However, this is not sufficient to doubt the authenticity of the Mizän, but it does throw light on the influence of Isfahani on Al-Ghazāti.

10. Abul Qasim al-Husayn b. Muhammad b. al-Mufaddal al-Rhāghib al-Ișfahânī, Kitab al-Dharì'ah ila Makārim al-Sharīah, ed. Abul-Yazid al-'Ajami (Cairo, 1987).

11. Mohamed Ahmed Sherif, Ghazāti's Theory of Virtue. (New York, 1975), p. 171.

12. Winter refers to Greek, Neoplatonic, and Muslim philosophers' influences, and cites sources with precise page references. He also cites from secondary scholarly works in French, German, and English. The explanatory notes of terms and concepts are also very helpful to the reader.

Winter has used a pleasing standard transliteration system for all Arabic terms, names, and titles. Abbreviations MA \& $\mathrm{Z}$ in notes to translation are not given in the list of abbreviations (xii); these are the 1928 and 1311 editions to which Winter refers to for variants and discrepancies in Arabic. The omissions are also indicated.

In the endnotes, Winter gives reference to the Qur'an and hadith citations, and quotations in the text are also cross-referenced to other sources. The footnotes are presented alphabetically after each section; the author provides explanatory notes for the Arabic terms and also refers other primary and secondary sources where this term is used.

13. Peter Newmark, A Textbook of Translation (New York: Printice Hall, 1988), pp. $184-192$.

14. Richard Jacquemond, "Translation and Cultural Hegemony: The Case of FrenchArabic Translation," in Rethinking Translation, ed. Laurence Venuti (London and New York, 1988), p. 149.

15. Mawardi and Isfahani weave into the Adab al-Dïn wa Dunyā and al-Dharïah ila Makärim al-Shariah (respectively), poetic verses, but their literary style is rich in rhymed prose.

16. H. Coombes, Literature and Criticism (Middlesex, 1953), p. 43-44.

17. In the Nicomachean Ethics, too, Aristotle had made use of the medical metaphor, and several Arab philosophers used the phrase "spiritual physic" (tibbräni) as the title of the book; Al-Farabi is also interested in the theme. This had appeared also in the more mainstream Islamic tradition: Junayd composed a brief epistle called "The Medicine of the Hearts," while the image of the Shaykh as a spiritual physician whose prescriptions must be followed is common throughout Sufism.

18. Aristotle, The Nicomachean Ethics, tr. J.A.K. Thomson (London, 1976). See also Abdurrahman Badawi (ed.), Ibn Hunayn -Kitāb al-Akhlāq [Arabic translation of The Nicomachean Ethics] (Kuwait, 1979), p. 170.

19. Abū 'Ali Ahmad b. Muhammad Miskawayh, Tahdhīb al-Akhlāq, ed. Constantine Zurayk (Beirut, 1966). English Translation. See Constantine K. Zurayk, The Refinement of Character [English translation of Miskawayh's Tahdhïb al-Akhläq] (Beirut, 1968), p. 20.

20. It is probably a high sense of morality that caused Aristotle to judge critically the shameful person for the wrong he has done in the first place. The Islamic law, however, allows the person to be remorseful and repentant; to feel a sense of shame, albeit in reaction to people's criticism. Aristotle's approach reminds one of the Sufi philosophy where good is done for the love of God, rather than out of fear of His punishment. Unfortunately, Winter has left the reader with a negative impresssion of Aristotle's view, which could have been avoided if he had provided an explanatory note to clarify the sense in which Aristotle did not recognize the quality of shame as a virtue. 